Egyptian Poultry Science Journal

http://www.epsaegypt.com

ISSN: 1110-5623 (Print) - 2090-0570 (On line)

EPSA

\title{
EFFECT OF USING BEE PROPOLIS AS NATURAL SUPPLEMENT ON PRODUCTIVE AND PHYSIOLOGICAL PERFORMANCE OF JAPANESE QUAIL
}

\author{
H. S. Zeweil' ${ }^{1}$, S. M. Zahran', M. H. A. Abd El-Rahman¹, W. M. Dosoky', Salma H. \\ Abu Hafsa ${ }^{2}$ and A. A. Moktar ${ }^{1}$ \\ ${ }^{1}$ Dep. of Anim. and Fish Prod., Fac. of Agric. (Saba Basha), Univ. of Alexandria. \\ ${ }^{2}$ Department of Livestock Research, Arid Lands Cultivation Research Institute, City of \\ Scientific Res. and Tech. App., New Borg El-Arab, P.O. Box 21934, Alexandria, Egypt
}

Received: 15/ 01/2016 Accepted: 15/02/2016

\begin{abstract}
This study was conducted to investigate the effect of supplementing bee propolis as a growth promoter and antioxidant material on laying performance, egg quality traits, blood parameters, antioxidant status during laying period of quails. A total number of 72 laying quails, 15-wks-old were randomly divided into four groups, 18 birds each, and each treatment replicated three times in a completely randomized design. The birds were selected on basis of more than $70 \%$ egg production rate after two-week of observation period. Dietary treatments were as follows: control (without supplementation), bee propolis at levels of 250 and $500 \mathrm{mg} / \mathrm{kg}$ diet and ascorbic acid at level $250 \mathrm{mg} / \mathrm{kg}$ diet (as a positive control). Results showed that quails fed diets supplemented with different levels of propolis or ascorbic acid had similar body weight change, egg laying rate, egg weight and egg mass as compared to those fed the control diet throughout the experiment. Feeding quails on different levels of propolis or ascorbic acid in the diet improved feed conversion ratio, but differences were not significant compared to the control. All studied egg quality parameters were not significantly affected by different treatments. Yolk total cholesterol concentration was significantly $(\mathrm{P} \leq 0.05)$ lower for groups fed $500 \mathrm{mg}$ propolis diet and this decrease reached to $3.6 \%$ as compared to those fed the control diet, whereas, yolk total lipids were significantly $(\mathrm{P} \leq 0.05)$ decreased for groups fed ascorbic acid or different levels of propolis as compared to the control group. The decrease in yolk total lipids reached to 18.9, 23.5 and $10.2 \%$ for the groups given $250 \mathrm{mg}$ ascorbic acid, 250 and $500 \mathrm{mg}$ propolis / $\mathrm{kg}$ diet, respectively. The studied serum constituents were significantly influenced for quails fed ascorbic acid or different levels of propolis diets. Feeding both ascorbic acid and propolis supplementation diets resulted in significantly lower total lipids, triglycerides, total cholesterol and LDL values than those fed the control diet. Malondialdehyde was significantly decreased whereas, total antioxidant capacity and glutathione peroxidase significantly increased in all treatments compared to the control. In conclusion, results indicated that propolis could effectively be added to quail ration to improve laying performance and to optimize lipid profile in egg yolk and blood and enhance the antioxidative status under summer conditions.
\end{abstract}

Key Words: Quail, Bee propolis, Ascorbic acid, Laying performance, Blood parameters.

Corresponding auther : hashim_salma@yahoo.com 


\section{INTRODUCTION}

Factors causing stress include physiological factors such as climate, environment, nutrition, and diseases, and physical conditions, such as cage density and transport (Freeman, 1987). Under stress, rapid and temporary changes occur in the body initially; with continuous stress, these are followed by permanent and irreversible changes. Finally, a decline in yield and resistance to diseases may occur. Animals under stress become ill more easily, and excess medicine may be necessary to maintain health. As a result, drug residues increase in animal products and threaten public health directly. Stock health and welfare management are key factors in animal health and food safety. For this reason, stress conditions in animals need to be examined carefully (Onbaşılar and Aksoy, 2005). The suitable temperature for poultry is between $16-25^{\circ} \mathrm{C}$ (Filizciler et al., 2002; Cerci et al., 2003). Heat stress begins when the ambient temperature climbs above $25^{\circ} \mathrm{C}$ and is readily apparent above $30^{\circ} \mathrm{C}$. Heat stress in laying hens is prompted by combinations of environmental temperature and humidity that prevent the bird's thermoregulatory process from effectively dissipating the heat produced during metabolism (Webster, 1983). High environmental temperatures the major problem faced by laying hens as well as by poultry farmers, usually in summer months. Heat stress in laying hens reduces live weight gain, feed intake, feed efficiency; production and quality of eggs and increases mortality (Ciftci et al., 2005). Researchers have tried to minimize the effect of heat stress by changing the environment and diets of laying hens. Environmental approaches include increasing the air flow over birds to increase heat loss, by increasing ventilation rates or by using evaporative cooling systems in enclosed houses and lowering stocking densities. Nutritional modifications usually made are the optimization of diets to meet the altered needs of stressed birds for protein and energy and for providing some additional nutrients. Because it is expensive to cool poultry houses, methods are focused mainly on nutritional modifications. For this aim, antioxidants such as ascorbic acid (vitamin C) and natural materials including antioxidants like propolis are used in the poultry diet because of their anti-stress effects and also because their synthesis is reduced during heat (Tatli Seven et al., 2006; Ipek et al., 2007; TatliSeven et al., 2008).

Vitamin $\mathrm{C}$, or L-ascorbic acid, is a watersoluble vitamin widely distributed in plants and animals. It is of major importance in nutrition to maintain a good health status. Generally, ascorbic acid is not regarded as a dietary requirement for poultry because it can be synthesized at a sufficient rate to meet the needs under normal conditions. Mayand McNaughton (1980) could not demonstrate apositive effect of $0.1 \%$ ascorbic acid supplementation on body weight of broiler chickens and did not found any effects on thyroid hormone functions. However, dietary vitamin $\mathrm{C}$ has been reported to improve resistance to a variety of stress or including environmental (e.g. heat stress), nutritional and pathological conditions (Agudelo, 1983). Several studies revealed a beneficial effect of vitamin $\mathrm{C}$ supplementation on growth rate, egg production, egg shell strength and thickness in stressed laying hens and broilers (Bains, 1996; TatliSeven, 2006).

Propolis is an adhesive, dark yellow to brown colored balsam that smells like resin. It is collected from buds, leaves and similar parts of trees and plants by bees and mixed with wax, sugar and plant exudates collected by bees from certainplant sources. More than 300 constituents have been identified in different propolis samples (Valle, 2000; Banskota et al., 2001; Shalmany and Shivazad, 2006). Propolis usually contains variety of chemical compounds, such as polyphenols 
(flavonoids, phenolic acids and their esters), terpenoids, steroids and amino acids. The composition of propolis depends on the vegetation at the site of collection (Kumazawa et al., 2003). Propolis has many positive effects like increase in feed intake, body weight increase, flavonoid content, taste improvement, antioxidant and antimicrobial properties. Antioxidative, cytostatic, anti-mutagenic and immune modulatory properties of propolis are based on its rich, flavonoid, phenolic acid and terpenoid contents (Kimoto et al., 1999; Prytzyket al., 2003; Wang et al., 2004). Although it is known that propolis is effective in cell membrane similarly to vitamin $\mathrm{C}$ in oxidative stress conditions. The objective of this study was to compare the efficacy of propolis and ascorbic acid as antioxidants in amelioration of heat stress impact and improving performance of laying Japanese quail under Egyptian summer conditions.

\section{MATERIALS AND METHODS}

The present study was carried out at the Poultry Research Laboratory, Department of Animal and Fish Production, Faculty of Agriculture (Saba Basha), Alexandria University, Egypt. The experiment was conducted in summer season of Alexandria city from July to September 2014, and the average temperature was $30^{\circ} \mathrm{C}$. Seventytwo laying hens, 15-wks-old weeks were randomly divided into four groups, 18 birds each and each treatment replicated three times in a completely randomized design. The birds were selected on basis of more than $70 \%$ egg production rate after twoweek of observation period. Dietary treatments were as follows: control (without supplementation), bee propolis at levels of 250 and $500 \mathrm{mg} / \mathrm{kg}$ diet and ascorbic acid at level $250 \mathrm{mg} / \mathrm{kg}$ diet. All quails were reared in wire batteries under the same managerial, hygienic and environmental conditions. Light regimen was (16L: 8D) for 8 weeks from July to September. Feed and water were available ad libitum all the time throughout the experimental period. The basal diet was formulated to meet the birds dietary nutrient requirements (NRC, 1994). It contained $20 \%$ crude protein and 2903 $\mathrm{kcal} / \mathrm{kg}$ metabolizable energy, the composition of basal diet is shown in Table 1. Body weight and feed consumption were recorded weekly. Feed conversion ratio was calculated ( $\mathrm{g}$ feed / g egg). Egg production, number of eggs, egg weight and mortality rate were monitored daily. Egg quality measurements were conducted using an average of 21 eggs from each treatment and were performed through two consecutive days per month. Shell thickness was determined from measurements of the mean thickness at three locations on the egg (air cell, equator and sharp end) using a dial pipe gauge (Mitutoyo, 0.01-20 mm, Tokyo, Japan). Yolk cholesterol was determined by nine eggs from each treatment and measured by the method of Folch et al., (1956) as modified by Washburn and Nix (1974).

At the end of the experiment, blood samples were collected from the brachial vein of 6 hens randomly chosen from each group then serum were immediately centrifuged at 3500 r.p.m. for $15 \mathrm{~min}$. and stored at $-18^{\circ} \mathrm{C}$ until use. Serum total protein, albumin, creatinine, uric acid, alkaline Phosphates, total lipids, triglycerides, cholesterol, HDL, LDL cholesterol, glutamic-pyruvate transaminase (GPT), glutamic-oxaloacetic transaminase (GOT), total antioxidant capacity, glutathione peroxidase and malondialdehyde (MDA) were calorimetrically determined using commercial kits (Biomerieux, Poains, France). The proximate chemical analysis of diet was determined according to AOAC (2005).

Data were analyzed by analysis of variance using the general linear model procedure (Proc GLM; SAS Institute, 1996). For the overall means, data was classified according to 4 treatments and the mean of each treatment was used. Differences 
among means were determined using Duncan test (Duncan, 1955).

\section{RESULTS AND DISCUSSIONS}

No significant differences in body weight change, egg laying rate, egg weight, egg number and egg mass due the supplementing ascorbic acid or different levels of propolis as compared with the control group throughout the experiment (Table 2). In a study conducted by Nockels (1988) indicated that supplementing 2,600 $\mathrm{mg} / \mathrm{kg}$ of ascorbic acid, egg production was not affected as compared with birds given control diet. On the other hand, Attia et al. (2015) found that vitamin $C$ resulted in higher $(\mathrm{P} \leq 0.05)$ body weight change, egg number, egg weight, egg mass and egg production in Dokki-4 laying hens through Egyptian summer season. Ozkok et al. (2013) reported that different propolis doses, 100, 200 and $400 \mathrm{mg} / \mathrm{kg}$ diet did not have significant effects on egg production and egg weight of Bevans White strain laying hens. Tayeb and Sulaiman (2014) showed that the propolis supplementation had not been significantly affected the egg production. Our results are contrast with the finding of Galal et al. (2008) who reported that egg number/hen was significantly increased by feeding diet supplemented with 100 and $150 \mathrm{mg}$ propolis $/ \mathrm{kg}$ diet during laying period. Tatli Seven (2008) reported that egg production and egg weight were significantly improved by feeding diets supplemented with vitamin C and propolis for laying hens reared under heat stress conditions.

The results in Table (2) showed insignificant decrease in feed consumption for the group given $250 \mathrm{mg}$ propolis $/ \mathrm{kg}$ diet as compared to the other experimental groups through the experiment. Ascorbic acid and $500 \mathrm{mg}$ propolis fed groups were equal to the control group. The obtained results were in agreement with those presented by Babaei et al. (2004) who reported that Japanese quail fed diet contained 1000 ppm alcoholic extract of propolis was not significantly affected feed consumption compared with the control quails. Also, Ozkok et al. (2013) reported that different propolis doses, 100,200 and $400 \mathrm{mg} / \mathrm{kg}$ diet did not have significant effects on feed consumption of Bevans White strain laying hens as compared with the control group. On the other hand, Tatli Seven et al. (2008) reported that propolis supplementation with $(5 \mathrm{~g} / \mathrm{kg})$ to laying diet had increased feed intake.

Feeding quails on different levels of propolis or ascorbic acid in the diet improved feed conversion ratio, but differences were not significant compared to the control. The group of birds received $250 \mathrm{mg}$ propolis $/ \mathrm{kg}$ diet improved by 3.9 $\%$ followed by $250 \mathrm{mg}$ ascorbic acid group $2.1 \%$ and $500 \mathrm{mg}$ propolis fed groups 1.8 $\%$ as compared with the control group, respectively. The improvement in feed conversion ratio may be due to the ability of bee propolis to improving nutrients digestibility and absorption as a result to improvement the activities of saccharase, amylase and phosphatase (Marieke et al., 2005) or easily prepared enzymatic hydrolysates from using two gastrointestinal proteases (pepsin and trypsin) and a protein (papain) protease (Kročko et al., 2012). Also, may be due to gut microflora is a nutritional "burden" in fast-growing broiler chickens, since an active microflora component may have an increased energy requirement for maintenance and a reduced efficiency of nutrient utilization (Dibner and Richards, 2005 and Lan et al., 2005). These results are similar with those obtained by VillarPatino et al. (2002) who reported that feed efficiency increased statistically with antioxidant supplementation. Some researchers demonstrated that when propolis was added to broiler chickens diets under heat stress conditions at $5 \mathrm{~g} / \mathrm{kg}$ (TatliSeven, 2008), at doses of 200 and $250 \mathrm{mg} /$ $\mathrm{kg}$ (Roodsari et al., 2004) and 1000 
$\mathrm{ppm} / \mathrm{kg}$ (Ziaran et al., 2005) and to quail diets at doses of $0.5,1.0$ and $3.0 \mathrm{~g} / \mathrm{kg}$, improved feed conversion ratio. Also, Attia et al. (2015) found that vitamin C supplementation in the diet of Dokki-4 laying hens through Egyptian summer season resulted in higher $(\mathrm{P} \leq 0.05)$ feed intake and improved feed efficiency.

Results of Table (3) showed insignificant differences in all egg quality parameters except yolk index significantly $(\mathrm{P} \leq 0.05)$ affected due to feeding the experimental diets. Propolis $500 \mathrm{mg} / \mathrm{kg}$ fed groups had significantly $(\mathrm{P} \leq 0.05)$ the highest yolk index value as compared to the other groups. Our findings are in agreement with earlier reports Nockels (1988) showed that egg shell thickness of birds was insignificantly affected by supplementing $2,600 \mathrm{mg} / \mathrm{kg}$ of ascorbic acid compared with the control. Also, (Silici et al., 2006) indicated that the addition of propolis at levels of $0.5,1.0,3.0$ and $6.0 \mathrm{~g} / \mathrm{kg}$ to rations of laying hens, at levels of 2.0 and $5.0 \mathrm{~g} / \mathrm{kg}$ in laying hens (Tatli-Seven, 2008), at levels of 1.0 and $4.0 \mathrm{~g} / \mathrm{kg}$ in quail (Silici and Guclu-Kocaoglu, 2010) did not affect egg quality traits under heat stress. Ozkok et al. (2013) stated that different propolis levels (100, 200 and 400 $\mathrm{mg} / \mathrm{kg}$ diet) did not have significant effects on egg quality criteria $(\mathrm{P} \leq 0.05)$ for Bevans White strain laying hens as compared with the control group. On the other hand, Tatli Seven (2008) reported that propolis supplementation increased egg shell thickness and egg shell weight in heat stressed laying hens. Yolk total cholesterol concentration was significantly $(\mathrm{P} \leq 0.05)$ lower for groups fed $500 \mathrm{mg}$ propolis diet and this decrease reached to $3.6 \%$ as compared to those fed the control diet, whereas, yolk total lipids were significantly $(\mathrm{P} \leq 0.05)$ decreased for groups fed ascorbic acid or different levels of propolis as compared to the control group. The decrease reached to $18.9,23.5$ and $10.2 \%$ for the groups given $250 \mathrm{mg}$ ascorbic acid,
250 and $500 \mathrm{mg}$ propolis/ $\mathrm{kg}$ diet, respectively (Table 3 ).

The results in Table (4) indicated that the different treatments induced significant changes in blood serum total protein and globulin concentration. Serum total protein was significantly higher by $6.3 \%$ for the group fed $500 \mathrm{mg}$ proplois $/ \mathrm{kg}$ diet, whereas, Albumin was insignificantly higher by feeding $500 \mathrm{mg}$ proplois $/ \mathrm{kg}$ diet as compared to those fed the control diet. Also, diet contained $500 \mathrm{mg}$ propolis showed significant $(\mathrm{P} \leq 0.05)$ increase in globulin level as compared to the control group. Ascorbic acid had insignificant effect on serum protein fractions. This implies that ascorbic acid or propolis used in the present study did not impair the synthesis and concentration of serum total protein, albumin and globulin. The significant increase of protein and globulin concentration may be attributed to the increase in the level of metabolic processes. Mahmoud et al. (2014) showed that addition of low dose of propolis (250 $\mathrm{mg} / \mathrm{kg}$ ) insignificantly increased serum total protein and globulin values, but the highest dose $(750 \mathrm{mg} / \mathrm{kg})$ had conversely affect. Abdel-Rahman and Mosaad, (2013) indicated that adding propolis $(2 \mathrm{~g} / \mathrm{kg})$ to the diet of Muscovy ducks maintained at $33^{\circ} \mathrm{C}$ was reflected with significant higher contents of its serum total protein, albumin and total globulin. Also they attributed the improvement of serum total protein and its fractions in the group fed propolis may be related to its stimulating effect on the liver exhibiting anabolic action favoring protein synthesis and also it's preserving effect on the body protein from degeneration. Attia et al. (2015) reported that ascorbic acid increased serum concentrations of total protein, albumin and globulin in laying hens as compared with the control group. Also, Sahin et al. (2002) reported that serum total protein and albumin concentrations increased with vitamin $\mathrm{C}$ supplementation. However, Konca et al. (2014) reported that dietary ascorbic acid 
(150 or $300 \mathrm{mg} / \mathrm{kg}$ ) was not significantly affected blood serum total protein, albumin and globulin of turkeys under summer temperatures that do not exceed $31.7^{\circ} \mathrm{C}$.

Results in Table 4 indicated a significant $(\mathrm{P} \leq 0.05)$ decrease in serum creatinine and uric acid due to feeding the different experimental diets. This may due to decreasing the load of the oxidative stress in quails according to the antioxidative proprties of the treatments which lead to better function of kindney. Serum GOT and GPT concentrations were significantly decreased for the groups fed the different experimental diets as compared to the control. The decrease was more pronounced $(\mathrm{P} \leq 0.05)$ with propolis than with ascorbic acid. Konca et al. (2009) reported that dietary ascorbic acid (150 or $300 \mathrm{mg} / \mathrm{kg}$ ) was not significantly affected blood serum urea and uric acid and GPT, however, it significantly decreased serum GOT as compared with the control group in turkeys reared under summer temperatures that do not exceed $31.7 \mathrm{C}$

Serum total lipids, triglycerides, total cholesterol and LDL cholesterol were significantly decreased, however, Serum HDL cholesterol was significantly increased by feeding diets supplemented with Ascorbic acid and different levels of propolis as compared with those fed the control diet. Generally, cholesterol is primarily biosynthesized in the liver of laying hens and incorporated into vitellogenin and very low density lipoprotein particles, which are secreted into the blood stream and subsequently taken up by growing oocytes through receptor mediated endocytosis (Elkin, 2006). The decrease in triglycerides and cholesterol may be attributed to propolis that play a major role as antioxidant material which increased glutathione enzyme activity, or/ and propolis contains some components such as essential fatty acids which inhibit hepatic 3-hydroxy-3methylglutaryl coenzyme A (HMG-CO A) reductase activity (Crowell, 1999) which is a key regulatory enzyme in cholesterol synthesis. These results are in agreement with those obtained by Babaei et al. (2004) who reported that Japanese quail diet containing $1000 \mathrm{ppm}$ alcoholic extract of propolis significantly lowered total cholesterol, triglycerides and LDL cholesterol and increased level of HDL cholesterol in the blood as compared with quail fed control diet. Awad et al. (2013) found that serum LDL cholesterol was significantly decreased by 18.83 and $17.94 \%$ for the hens fed diet supplemented with 1.0 and $1.5 \mathrm{~g} \mathrm{BB} / \mathrm{kg}$, respectively as compared to the control. Also, Zhao et al. (1990) who reported that pollen extract lowered blood lipid levels in both animals and humans. Čeksteryte et al. (2008) reported that the effects of plant pollen and honey on the antioxidative processes and immune system have shown a decrease of lipid peroxidation in the blood. Similarly, Kolankaya et al. (2002) found that HDL level increased and LDL, cholesterol and triglycerides levels were decreased by giving propolis with $200 \mathrm{mg} / \mathrm{kg}$ body weight/day in rats. It was expressed in the findings of diverse studies that propolis intake lead to a decrease in the level of plasma triglycerids concentrations (Fuliang et al. 2005). This lowering effect can be attributed $o$ the regulatory mechanism of the flavanoids as one of the ingredients in these natural products for blood circulation and stimulation of triglycerids use for energy generation. (Tekeli et al, 2011). On the other hand, Daneshmand et al. (2015) reported that propolis supplementation in broiler chicken diet resulted in nonsignificant difference was detected with regard to serum lipid profile as compared with control. Also, Denli et al. (2005) demonstrated that propolis had no significant effect on triglycerides, total cholesterol, high density lipoprotein and low density lipoprotein in quail compared to the control.

Ascorbate is necessary for the transformation of cholesterol to bile acids 
by controlling the microsomal $7 \quad \alpha$ hydroxylation. As this reaction is the ratelimiting step of the cholesterol catabolism in the liver, ascorbic acid deficiency induces a marked deceleration of this reaction, leading to cholesterol accumulation in the liver and the blood (Naidu, 2003). In the present study, dietary ascorbic acid supplementation decreased serum cholesterol. The reduction of blood cholesterol concentrations due to the addition of ascorbic acid has been demonstrated in Ahmed et al. (2005). Similar to our results, Sahin et al. (2002) reported that serum triglycerides and cholesterol concentrations were decreased with inclusion vitamin $\mathrm{C}$ in the diet of chickens as compared with control group. Also, Konca et al. (2009) reported that dietary ascorbic acid (150 or $300 \mathrm{mg} / \mathrm{kg}$ ) caused a quadratic decrease in serum cholesterol and LDL in turkeys reared under summer temperatures that do not exceed $31.7 \mathrm{C}$.

Feeding laying Japanese quails on diets supplemented with Ascorbic acid at level $250 \mathrm{mg} / \mathrm{kg}$ diet and different levels of propolis 250 and $500 \mathrm{mg} / \mathrm{kg}$ diet during summer season resulted in decreased $(\mathrm{P} \leq 0.05)$ serum MDA but increased $(\mathrm{P} \leq 0.05)$ serum total antioxidant capacity and serum glutathione peroxidase as compared to the control group (Table 4). Quail hens fed $500 \mathrm{mg}$ propolis diet had the lowest level of serum MDA (as a marker of the oxidative stress and as an indicator of lipid peroxidation); this may refer to the strong antioxidant activity of propolis; due to the phenols compound in propolis. Also, Propolis prevents lipid oxidation because it contain chyrisin as one of the propolis compounds which having hepatoprotective and antioxidant activities (Sathiavelu et al.,
2009) also benzoic acid derivative exhibits antioxidant effects using inhibition assays of luminal luminescence, 2, 2-diphenyl-1picrylhydazyl and lipoperoxidation, particularly caffeic acid, caffeoylquinic acid and cinamic acid are effective $\mathrm{O}_{2-}$ scavenging activity (Christov et al., 2006; Nakajima et al., 2007). Besides, flavonoids inhibit lipid peroxidation, platelet aggregation, capillary permeability and fragility, and the activity of enzyme systems, including cyclooxygenase (COX) and lipoxygenase (Havsteen, 2002). It has been reported that phenolic compounds exhibit antioxidant activity which is correlated with health benefits (Kähkönen et al., 1999). Čeksteryte et al. (2008) reported that the effects of plant pollen and honey on the antioxidative processes and immune system have shown a decrease of lipid peroxidation in the blood. In addition, Attia et al. (2015) reported that vitamin C (ascorbic acid) significantly $(\mathrm{P} \leq 0.05)$ decreased cholesterol and MDA concentrations compared with the control group. Tatli-Seven et al. (2009) found that plasma MDA level was significantly decreased in vitamin $\mathrm{C}$ fed group compared to the control group. Heat stress causes increased free radical production (Halli well and Gutteridge, 1989) and lower the concentrations of antioxidant vitamins and minerals such as $\mathrm{E}, \mathrm{C}, \mathrm{A}$ and $\mathrm{Zn}$ in serum and tissues (Sahin and Kucuk, 2003).

\section{CONCLUSION}

Results indicated that propolis could effectively be added to quail ration to improve laying performance and to optimize lipid profile in egg yolk and blood and enhance the antioxidative status under summer conditions. 
Table (1): Composition and chemical analysis of the basal experimental diet.

\begin{tabular}{|c|c|}
\hline \multirow{2}{*}{ Ingredints } & Experimental diets \% \\
\hline & Laying \\
\hline Yellow corn & 55.50 \\
\hline Soybean meal (44 \%) & 24.50 \\
\hline Concentrate $(50 \%) *$ & 10.00 \\
\hline Di-calcium phosphate & 2.00 \\
\hline Limestone & 5.50 \\
\hline Sunflower oil & 2.50 \\
\hline Vit. and min. mix.** & 0.50 \\
\hline Salt $(\mathrm{NaCl})$ & 0.50 \\
\hline Total & 100 \\
\hline Calculated analyses $^{1}$ : & \\
\hline Crude protein, $\%$ & 20.00 \\
\hline ME (Kcal/ Kg diet) & 2903.89 \\
\hline Ether extract, \% & 2.60 \\
\hline Crude fiber, \% & 3.04 \\
\hline Methionine, \% & 0.71 \\
\hline Methionine + cystine, \% & 0.90 \\
\hline Lysine, \% & 1.15 \\
\hline Calcium, \% & 2.58 \\
\hline Av. phosphorus & 0.40 \\
\hline
\end{tabular}

* Concentrate : ME (K cal $/ \mathrm{kg}) 2870$, Crude protein $50 \%$, Crude fiber $1.51 \%$, Crude fat $1.54 \%$, Calcium 4.29\%, Phosphorus $2.39 \%, \mathrm{NaCl} 0.8 \%$, Methionine $4.6 \%$, Methionine \&Cystine $5.38 \%$, Lysine $3.90 \%$.

** Each kg of vitamin and minerals mixture contained: Vit. A, 4,000,000 IU; Vit. $\mathrm{D}_{3}, 500,000 \mathrm{IU}$; Vit, E, 16.7 g., Vit. K, 0.67 g., Vit. B1, 0.67 g., Vit. B2, 2 g., Vit. B 6, .67 g., Vit. B12, 0.004 g., Nicotinicacid, 16.7 g., Pantothenicacid, 6.67 g., Biotin, 0.07 g., Folicacid, 1.67 g., Choline chloride, 400 g., Zn, 23.3 g., Mn, 10 g., Fe, 25 g., Cu,1.67 g., I, 0.25 g.,Se, 0.033 g. and,Mg, 133.4 g. ${ }^{1}$ According to NRC (1994). 
Quail, Bee propolis, Ascorbic acid, Laying performance, Blood parameters.

Table (2): Effect of ascorbic acid and propolis on laying performance of Japanese quails.

\begin{tabular}{|l|c|c|c|c|}
\hline \multicolumn{1}{|c|}{ Items } & Control & $\begin{array}{c}\text { Ascorbic } \\
\text { acid (250 } \\
\mathbf{m g} / \mathbf{k g})\end{array}$ & $\begin{array}{c}\text { Propolis } \\
\mathbf{2 5 0} \mathbf{~ m g / k g}\end{array}$ & $\begin{array}{c}\text { Propolis } \\
\mathbf{5 0 0} \mathbf{~ m g} / \mathbf{k g}\end{array}$ \\
\hline Body weight Change (g) & $18.56 \pm 2.4$ & $14.49 \pm 2.2$ & $15.01 \pm 1.7$ & $16.47 \pm 1.6$ \\
Egg laying rate (\%) & $89.14 \pm 0.6$ & $87.99 \pm 1.5$ & $88.10 \pm 1.4$ & $86.86 \pm 0.9$ \\
Egg weight (g) & $13.22 \pm 0.2$ & $13.42 \pm 0.3$ & $13.53 \pm 0.2$ & $13.58 \pm 0.1$ \\
Egg number(hen/ day) & $0.89 \pm 0.01$ & $0.88 \pm 0.01$ & $0.88 \pm 0.01$ & $0.87 \pm 0.01$ \\
Egg mass(g/hen/day) & $11.78 \pm 0.2$ & $11.79 \pm 0.2$ & $11.92 \pm 0.3$ & $11.79 \pm 0.1$ \\
Feed consumption (g/hen/day) & $32.93 \pm 0.6$ & $32.23 \pm 0.7$ & $31.79 \pm 0.8$ & $32.44 \pm 0.8$ \\
Feed conversion ratio (g feed/g & $2.80 \pm 0.02$ & $2.74 \pm 0.09$ & $2.69 \pm 0.08$ & $2.75 \pm 0.05$ \\
egg) & & & & \\
\hline
\end{tabular}

Table (3): Effect of ascorbic acid and propolis on egg quality parameters of laying Japanese quails.

\begin{tabular}{|l|l|l|l|l|}
\hline Items & Control & $\begin{array}{l}\text { Ascorbic } \\
\text { acid (250 } \\
\text { mg/kg) }\end{array}$ & $\begin{array}{l}\text { Propolis } \\
\mathbf{2 5 0} \mathbf{~ m g / k g}\end{array}$ & $\begin{array}{l}\text { Propolis } \\
\mathbf{~ m g ~ / k g ~}\end{array}$ \\
\hline Egg weight(g) & $13.45 \pm 0.1$ & $13.51 \pm 0.2$ & $13.75 \pm 0.2$ & $13.39 \pm 0.2$ \\
Egg specific gravity & $1.077 \pm 0.00$ & $1.079 \pm 0.00$ & $1.080 \pm 0.00$ & $1.078 \pm 0.00$ \\
Egg shape index & $77.87 \pm 0.7$ & $78.17 \pm 0.9$ & $77.09 \pm 0.9$ & $77.73 \pm 0.8$ \\
Yolk index & $4.67 \pm 0.1^{\mathrm{ab}}$ & $4.44 \pm 0.2^{\mathrm{b}}$ & $4.42 \pm 0.1^{\mathrm{b}}$ & $4.98 \pm 0.1^{\mathrm{a}}$ \\
Yolk weight & $4.43 \pm 0.1$ & $4.41 \pm 0.1$ & $4.50 \pm 0.1$ & $4.34 \pm 0.1$ \\
Yolk weight (\%) & $32.64 \pm 0.4$ & $32.66 \pm 0.5$ & $32.77 \pm 0.4$ & $32.43 \pm 0.3$ \\
Yolk height(mm) & $10.40 \pm 1.0$ & $9.85 \pm 0.9$ & $11.17 \pm 0.3$ & $11.47 \pm 0.6$ \\
Yolk color & $4.50 \pm 0.3$ & $4.50 \pm 0.2$ & $4.60 \pm 0.3$ & $4.70 \pm 0.3$ \\
Albumin weight(g) & $7.79 \pm 0.1$ & $7.85 \pm 0.1$ & $7.96 \pm 0.1$ & $7.78 \pm 0.1$ \\
Albumin weight $(\%)$ & $57.92 \pm 0.4$ & $58.16 \pm 0.4$ & $57.88 \pm 0.4$ & $58.01 \pm 0.3$ \\
Albumin height & $3.00 \pm 0.2$ & $2.82 \pm 0.1$ & $2.92 \pm 0.1$ & $2.92 \pm 0.1$ \\
Egg shell thickness & $0.223 \pm 0.00$ & $0.222 \pm 0.01$ & $0.237 \pm 0.00$ & $0.221 \pm 0.00$ \\
Egg shell weight(g) & $1.27 \pm 0.03$ & $1.24 \pm 0.03$ & $1.29 \pm 0.02$ & $1.28 \pm 0.02$ \\
Egg shell (\%) & $9.44 \pm 0.2$ & $9.19 \pm 0.2$ & $9.40 \pm 0.2$ & $9.57 \pm 0.1$ \\
Yolk total Cholesterol (mg/g & $18.47 \pm 0.2^{\mathrm{a}}$ & $18.09 \pm 0.4^{\mathrm{ab}}$ & $18.34 \pm 0.2^{\mathrm{a}}$ & $17.80 \pm 0.3^{\mathrm{b}}$ \\
yolk) & & & & \\
Yolk total Lipids (mg/g yolk) & $323.3 \pm 0.2^{\mathrm{a}}$ & $262.0 \pm 0.1^{\mathrm{c}}$ & $247.2 \pm 0.1^{\mathrm{c}}$ & $290.2 \pm 0.2^{\mathrm{b}}$ \\
\hline
\end{tabular}

$\mathrm{a}-\mathrm{c}$ : different superscripts within a raw indicate significant differences $(\mathrm{P} \leq 0.05)$. 
Table (4): Effect of ascorbic acid and propolis on blood serum constituents of laying Japanese quails.

\begin{tabular}{|c|c|c|c|c|}
\hline Items & Control & $\begin{array}{l}\text { Ascorbic acid } \\
(250 \mathrm{mg} / \mathrm{kg})\end{array}$ & $\begin{array}{l}\text { Propolis } \\
250 \mathrm{mg} / \mathrm{kg}\end{array}$ & $\begin{array}{l}\text { Propolis } 500 \\
\mathrm{mg} / \mathrm{kg}\end{array}$ \\
\hline Total protein $(\mathrm{g} / \mathrm{dl})$ & $4.79 \pm 0.01^{\mathrm{b}}$ & $4.85 \pm 0.01^{\mathrm{b}}$ & $4.91 \pm 0.05^{\mathrm{ab}}$ & $5.11 \pm 0.01^{\mathrm{a}}$ \\
\hline Albumin $(\mathrm{g} / \mathrm{dl})$ & $3.09 \pm 0.03$ & $3.05 \pm 0.02$ & $3.03 \pm 0.05$ & $3.17 \pm 0.05$ \\
\hline Globulin (g/dl) & $1.70 \pm 0.08^{\mathrm{c}}$ & $1.79 \pm 0.06^{b c}$ & $1.87 \pm 0.05^{\mathrm{ab}}$ & $1.94 \pm 0.07^{\mathrm{a}}$ \\
\hline Creatinine (mg/dl) & $0.29 \pm 0.03^{\mathrm{a}}$ & $0.24 \pm 0.03^{b}$ & $0.24 \pm 0.02^{\mathrm{b}}$ & $0.23 \pm 0.02^{b}$ \\
\hline Uric acid (mg/dl) & $4.98 \pm 0.1^{\mathrm{a}}$ & $4.32 \pm 0.1^{\mathrm{b}}$ & $4.35 \pm 0.2^{\mathrm{b}}$ & $4.24 \pm 0.2^{\mathrm{b}}$ \\
\hline $\begin{array}{l}\text { Alkaline Phosphates } \\
\text { (U/L) }\end{array}$ & $96.91 \pm 3.5^{\mathrm{a}}$ & $92.08 \pm 3.1^{\mathrm{b}}$ & $87.90 \pm 3.1^{\mathrm{c}}$ & $85.09 \pm 2.9^{\mathrm{d}}$ \\
\hline GOT (U/L) & $82.00 \pm 1.8^{\mathrm{a}}$ & $80.25 \pm 1.4^{\mathrm{b}}$ & $78.25 \pm 1.7^{\mathrm{c}}$ & $75.75 \pm 1.6^{\mathrm{d}}$ \\
\hline GPT (U/L) & $77.13 \pm 1.0^{\mathrm{a}}$ & $73.88 \pm 1.9^{\mathrm{b}}$ & $69.88 \pm 2.2^{\mathrm{c}}$ & $66.38 \pm 1.9^{\mathrm{d}}$ \\
\hline Total Lipids (mg/dl) & $1141.63 \pm 51.20^{\mathrm{a}}$ & $1046.38 \pm 47.90^{\mathrm{b}}$ & $996.50 \pm 52.40^{c}$ & $932.63 \pm 46.10^{\mathrm{d}}$ \\
\hline Triglycerides (mg/dl) & $731.50 \pm 40.4^{\mathrm{a}}$ & $671.25 \pm 40.9^{\mathrm{b}}$ & $621.00 \pm 39.6^{c}$ & $554.89 \pm 39.8^{\mathrm{d}}$ \\
\hline $\begin{array}{l}\text { Total cholesterol } \\
(\mathrm{mg} / \mathrm{dl})\end{array}$ & $192.60 \pm 5.9^{\mathrm{a}}$ & $182.42 \pm 6.3^{\mathrm{b}}$ & $175.28 \pm 6.4^{\mathrm{c}}$ & $130.31 \pm 5.9^{c}$ \\
\hline $\mathrm{LDL}(\mathrm{mg} / \mathrm{dl})$ & $5.89 \pm 0.2^{\mathrm{a}}$ & $5.18 \pm 0.3^{b}$ & $5.21 \pm 0.2^{b}$ & $4.70 \pm 0.2^{c}$ \\
\hline HDL (mg/dl) & $51.65 \pm 1.1^{\mathrm{c}}$ & $55.83 \pm 2.2^{\mathrm{b}}$ & $56.50 \pm 1.8^{\mathrm{b}}$ & $59.69 \pm 1.4^{\mathrm{a}}$ \\
\hline $\begin{array}{l}\text { Malondialdehyde } \\
(\mathrm{nmol} / \mathrm{ml})\end{array}$ & $9.31 \pm 0.8^{\mathrm{a}}$ & $7.16 \pm 0.2^{b}$ & $7.11 \pm 0.1^{b}$ & $6.91 \pm 0.1^{\mathrm{c}}$ \\
\hline $\begin{array}{l}\text { Total antioxidant } \\
\text { Capacity ( } \mathrm{mM} / \mathrm{L})\end{array}$ & $0.78 \pm 0.06^{\mathrm{c}}$ & $0.94 \pm 0.07^{\mathrm{a}}$ & $0.85 \pm 0.04^{b}$ & $0.94 \pm 0.05^{\mathrm{a}}$ \\
\hline $\begin{array}{l}\text { Glutathione } \\
\text { peroxidase }(\mathrm{mU} / \mathrm{ml})\end{array}$ & $23.83 \pm 0.7^{\mathrm{c}}$ & $27.46 \pm 1.1^{\mathrm{ab}}$ & $25.79 \pm 1.3^{\mathrm{bc}}$ & $29.35 \pm 1.3^{\mathrm{a}}$ \\
\hline
\end{tabular}

a - d: different superscripts within a raw indicate significant differences $(\mathrm{P} \leq 0.05)$. 


\section{REFERENCES}

Abdel-Rahman, M. A. and G. M. Mosaad (2013). Effect of Propolis as Additive on Some Behavioural Patterns, Performance and Blood Parameters in Muscovy Broiler Ducks. Journal of Advanced Veterinary Research. 3, 6468.

Ahmed, N., S. Haldar, M. C. Pakhira and T. K. Ghosh (2005). Growth performances, nutrient utilization and carcass traits in broiler chickens fed with a normal and a low energy diet supplemented with inorganic chromium (as chromium chloride hexahydrate) and a combination of inorganic chromium and ascorbic acid. Journal of Agricultural Science, 143: 427- 439.

Agudelo, L. G. (1983). Possible causes of avian odema, International Journal of Poultry Sci. 22: 8-14.

A.O.A.C. (2000). Official methods of analysis $15^{\text {th }}$ ed A.O.A.C. Washington, DC.

Attia, K. H. M., F. A. Tawfeek; M. S. Mady and M. H. Assar (2015). Effect of dietary chromium, selenium and vitamin $\mathrm{C}$ on productive performance and some blood parameters of local strain Dokki-4 under Egyptian summer conditions. Egypt. Poult. Sci. Vol (35) (I): 311-329.

Awad, A. L.; M. M. Beshara; A. F. Ibrahim and H. N. Fahim (2013). Effect of using bee bread as a natural supplement on productive and physiological performance of local sinai hens. Egypt. Poult. Sci. Vol (33) (IV): (889-913).

Babaei, S., S. Rahimi, M. A. Karimi Torshizi, N. Khaleghi Miran, G. A. Nehzati and N. Razmgah (2004). Effects of propolis, honey, royal jelly, and bee pollen on the growth performance and blood parameters of quail (Coturnix coturnix japonica). Poult. Sci. (E-suppl.1): 389 P.
Bains, B. S. (1996). The role of vitamin C in stress management. World Poult.,12: (4): 38-41.

Banskota, A. H., Y. Tezuka and S. Kadota (2001). Recent progress in pharmacological research of propolis. Phytotherapy Research 15: 561-571.

Čeksterytė , V., J. Račys, V. Kaškonienè and P. R. Venskutonis (2008). Fatty acid composition in beebread. Biolog. Sci. Vol., 54 (4): 253-257.

Cerci, I. H., P. Tatli, M. A. AzmanandN.Birben (2003). The effect of restricted feed on feed intake, egg production and feed conversion in pullets. Indian Vet. J., 80:1153-1157.

Christov, R., B. Trusheva, M. Popova, V. Bankova and $M$. Bertrand (2006). Chemical composition of propolis from Canada, its antiradical activity and plant origin. Natural Product Research, Vol. 20 (6): 531-536.

Ciftci, M., O. N. Ertaş and T.Guler (2005). Effects of Vitamin $E$ and Vitamin C dietary supplementation on egg production and egg quality of laying hens exposed to a chronic heat stress. Revue Med.Vet.156:107-111.

Crowell, P. L. (1999). Prevention and therapy of cancer by dietary monoterpenes. J. Nutr., 129: 775S-778S.

Daneshmand, A., GH. Sadeghi, A. Karimi, A. Vaziry and S. A. Ibrahim (2015). Evaluating complementary effects of ethanol extract of propolis with the probiotic on growth performance, immune response and serum metabolites in male broiler chickens. Livestock Science 178: 195201.

Denli, M., S. Cankaya, S. Silici, F. Okan and A. N. Uluocak (2005). Effect of dietary addition of Turkish propolis on the growth performance, carcass characteristics and serum variables of quail (Coturnixcotur-nix japonica). Asian-Australas. J. Anim. Sci. 18, 848854. 
Dibner, J. J. and J. D. Richards (2005). Antibiotic growth promoters in agriculture: History and mode of action, Poultry Science, 84: 634- 643.

Duncan, D. B. (1955). Multiple range and F., test Biometric. 11:42.

Elkin, R. G. (2006). Reducing shell egg cholesterol content. I. Overview, genetic approaches, and nutritional strategies. World's Poult. Sci., 62: 665-687.

Filizciler, M., I. H. Cerci and P. Tatli (2002). Effects of night feeding on SPF (Specific Pathogen Free) white egg layers under heat stress (in Turkish). Turkish J. Vet. Anim. Sci. 26:439-446.

Folch, J., M. Less and G. H. S. Stanley (1957).A simple method for the isolation and purifcation of total lipids from animal tissues. J. Biol. Chem., 226:497509.

Freeman, B. M. (1987). The stress syndrome. World Poult. Sci. J., 43, 1519.

Fuliang, H. U., H. R. Hepburn, H. Xuan, M. Chen, S. Daya and S. E. Radloff (2005). Effects of propolis on blood glucose, blood lipid and free radicals in rats with diabetes mellitus. Pharmacology Research 51:147-152.

Galal, A., A. M. Abd El-Motaal, A. M. H. Ahmed and T. G. Zaki (2008). Productive performance and immune response of laying hens as affected by dietary propolis supplementation. Inte. J. of Poult. Sci. 7 (3): 272-278.

Halliwell, B. E.; and Gutteridge, J. M. C. (1989). Lipid peroxidation: a radical chain reaction. In: Free Radicals in Biology and Medicine, $2^{\text {nd }}$ ed. Oxford University Press, New York, NY, pp. 188-218.

Havsteen, B. (2002). The biochemistry and medical significance of the flavonoids. Pharmacology and Therapeutic, 96, 67202.

Ipek, A., O. Canbolat and A. Karabulut. (2007). The effect of vitamin $E$ and vitamin $\mathrm{C}$ on the performance of Japanase
Quails(CoturnixCoturnicsJaponica)

rearedunderheatstress

duringgrowthandeggproductionperiod.A sian-Aust.J.Anim. Sci.20:252-256.

Kähkönen, M.P., A. I. Hopia and H. J. Vuorela (1999).Antioxidant activity of plant extracts containing phenolic compounds. Journal of Agricultural and Food Chemistry47,3954-3962.

Kimoto, Hirose, H., M. Masao, T. Sato, M. Hideki and T. Shira T. (1999). Post initiation effects of a super critical extract of propolis I a rat two-stage carcinogenesis model in female. Cancer Letters 147, 221-227.

Kolankaya, D., G. Selmanoglu, K. Sorkun and B. Salih (2002). Protective effects of Turkish propolis on alcoholinduced serum lipid changes and liver injury in male rats. Food Chem., 78: 213-217.

Konca, Y., F. Kirkpinar and M. Çabuk (2009). Effect of dietary ascorbic acid on blood hematological profile, serum biochemical components and tovic immobility reaction of male turkeys under summer condition. J. Poult. Sci. 46: 105-111.

Konca Y., H. Yalcin, M. Karabacak, M. Kaliber and F. Z. Durmuscelebi (2014). Effect of hempseed (Cannabis sativa L.) on performance, egg traits and blood biochemical parameters and antioxidant activity in laying Japanese Quail (Coturnixcoturnix japonica). British Poultry Science, 55(6): 785-794. Leizer C., Ribnicky D., Poulev A., Dushenkov S., Raskin I., 2000. The composition of hempseed oil and its potential as an important source of nutrition. Journal of Nutraceuticals, Functional and Medical Foods, 2(4): 35 53.

Kročko, M., M. Čanigová, J. Bezeková, M. Lavová, P. R. Haščík and V. Ducková (2012). Effect of nutrition with propolis and bee pollen supplements on bacteria colonization pattern in gastrointestinal tract of broiler 
chickens. Anim. Sci. and biotech., 45 (1):63-67.

Kumazawa, S., M. Yoneda, I. Shibata, J. Kanaeda, T. Hamasaka and T. Nakayama (2003). Direct Evidence for the Plant Origin of Brazilian Propolis by the Obsevation of Honeybee Behavior and Phytochemical Analysis. Chemical and Pharmaceutical Bulletin 51: 740742.

Lan, Y., M. W. Verstegen, S. Tamminga and B. A. Williams (2005). The role of the commensal gut microbial community in broiler chickens, World's Poultry Science Journal, 61: 95-104.

Mahmoud, U. T., M. R. Fahmey, M. A.Abdel-Rahman and M. H. A. Darwish (2014). Effect of Propolis Supplementation on Serum Calcium, Phosphorus and Proteins Concentrations in Heat Stressed Broilers. Journal of Advanced Veterinary Research, Vol. 4 (3): 117-122.

Marieke, M., H. Blitterswijk, L. Leven, J. Kerkvliet and J. Waerd (2005). Bee products (properties, processing and marketing). Agrodok 42, NECTAR, Netherlands Expertise Centre for (sub) Tropical Apicultural Resources, pp :3335.

May, J. D. and J. L. McNaughton (1980). Effects of dietary ascorbic acid, aspirin, lysine and thiouracil on thyroid activity. Poult. Sci. 59: 893-899.

Naidu, K. A. (2003). Vitamin C in human health and disease is still a mystery? An overview . Nutrition Journal 2: 1-10.

Nakajima, Y., M. Shimazawa, S. Mishima and H. Hara (2007). Water extract of propolis and its main constituents, caffeoylquinic acid derivatives, exert neuroprotective effects via antioxidant actions. Life Science 80: 370-377.

Nockels, C. F. (1988). The role of vitamins in modulating disease resistance. Vet. Clin. North America Food Anim. Prac. 4(3):531.
NRC, (National Research Council) (1994). Nutrient requirements of poultry. Nutrient Requirements of Domestic Animals. 9th rev. ed . Natl. Acad. Sci., Washington, DC.

Onbaşılar, E. E. and F. T. Aksoy (2005). Stresparameters and immune response of layers under different cage floor and density conditions. Livest. Prod. Sci. 95: 255-263.

Ozkok, D., K. M. Iscan and S. Silici (2013). Effects of Dietary Propolis Supplementation on Performance and Egg quality in Laying Hens. Journal of Animal and Veterinary Advances 12(2):269-275,

Prytzyk, E., A. Dantas, K. Salomao, V. Periera, S. Bakova, D. Castro and A. Eto (2003). Flavinoids adtrypanocidal activity of Bulgarian propolis. Journal of Ethnopharmacology 88, 189-193.

Roodsari, M. H., M. Mehdizadeh, F. B. Kasmani, H. Lotfelahian, F. Mosavi and A. H. Abolghasemi (2004). Effectsofoil-extracted propolisonthe performance of broylerchicks. Agricult. Sci. Technol.,18:57-65.

Sahin, K. and Kucuk, O. (2003). Heat stress and dietary vitamin supplementation of poultry diets. Nutr. Abstr. Rev. Ser. B Livest. Feed Feeding 73, 41R-50R

Sahin, K.; O. Ozbey; M. Onderci; G. Cikim, G. and M. H. Aysondu (2002). Chromium supplementation can alleviate negative effects of hot climate on egg production, egg quality and some serum metabolites of laying Japanese quail. J Nutr. 132: 1265-1268.

SAS 1996. SAS/STAT Software, Version 6.12 of the SAS system for windows, Copyright 1996. SAS Institute Inc., Cary, NC, USA.

Sathiavelu, J., G. J. Senapathy, R. Devara and N. Namasivayam (2009). Hepatoprotective effect on chrysin on prooxidant-antioxidant status during ethanol-induced toxicity in female 
albino rats. Journal of Pharmay and Pharmacology, 61: 809-817.

Shalmany, S. K. and M. Shivazad (2006). The effect of diet propolis supplementation on Ross broiler chicks performance. Int. J. Poult. Sci., 5: 84-88.

Silici, S. and B. Guclu-Kocaoglu (2010). Effect of dietary addition of propolis and caffeic acid on the growth performance, production and hatching performance, egg quality and some biochemical parameters of quail (Coturnix Coturnix japonica). Ere. Univ. J. Health Sci., 19: 94-104.

Silici, S., B. Guculu-Kocaoglu, F. Uyanik and M. K. Iscan (2006). Effects of dietary propolis supplementation on performance, egg quality and some biochemical parameters in laying hens. TUBITAK VHAG (104Vl 27)ResultReport.

Tatli-Seven, P. (2008). The effects of dietary Turkish Propolis and vitamin $\mathrm{C}$ on performance, digestibility, egg production and egg quality in laying hens under different environmental temperatures. Asian-Aust. J. Anim. Sci., 21:1164-1170.

Tatli Seven, P., I. Seven, M. Yılmaz and U. G. Şimşek (2008). The effects of Turkish propolis on growth and carcass characteristics in broilers under heat stress. Animal Feed Science and Technology, 146, 137-148.

TatliSeven, P. (2006). Effects of selenium and vitamin $\mathrm{C}$ supplemented high energy diet on physical performance, nutrient retention and relative organ weights in cold stressed broilers $\left(15^{\circ} \mathrm{C}\right)$. International Symposium on Selenium In Health And Disease, October 12-13, Ankara, Turkey,p.45.

TatliSeven, P., S. Yılmaz, I. Seven and B. Dalkılıç (2006). Effects of dietary supplementation of antioxidants (selenium and vitamin $\mathrm{C}$ ), triiodothyronine (T3) hormoneandiodine on biochemical parameters and antioxidant enzyme activities in colds tressed broilers $\left(15^{\circ} \mathrm{C}\right)$. International Symposium on Seleniumin Health and Disease, October 12-13, Ankara, Turkey, p. 44.

Tayeb, I. T. and B. F. Sulaiman (2014). Effect of propolis supplementation on productive performance in local quail. Iranian Journal of Applied Animal Science 4 (3): 621-627.

Tekeli, A., H. R. Kutlu and L. Celik (2011). Effects of $Z$. officinale and propolis extracts on the performance, carcass and some blood parameters of broiler chicks. Current Research in Poultry Science1(1):12-23.

Valle, M. L. (2000). Quantitative determination of antibacterian capacities of propolis. Apiacta Journal 35: 152161.

Villar-Patino, G., A. Diaz-Cruz, E. AvilaGonzalez, R. Guinzberg, J. L. Pablos and E. Pina (2002). Effects of dietary Supplementation with vitamin $\mathrm{C}$ or vitamin $\mathrm{E}$ on cardiac lipid peroxidation and growth performance in broilers. Am. J. Vet. Res. 63(5):673-676.

Wang, B. J., Y. H. Lien and Z. R. Yu (2004). Supercritical fluid extractive fractionation-study of the antioxidant activities of propolis. Food Chemistry 86: 237-243.

Washburn, K. W. and D. F. Nix (1974). Genetic basis of yolk cholesterol content. Poultry Sci. 53: 109-115.

Webster, A. J. F. (1983). Nutrition and the thermal environment in nutritional physiology of farm animals (Ed. J. A. F. Rook and P. C. Thomas). New York, Longman, pp. 639-669.

Zhao, J., C. Y. Zhang and D. M. Xu (1990). The antiatherogenic effects of components isolated from pollen typhae. Thromb Res., 57: 957-966.

Ziaran, H. R., H. R. Rahmani and J. Pourreza (2005). Effect of dietary oil extract of propolis on immune response and broiler performance. Pak. J. Biol. Sci., 8:1485-1490. 


\section{الملخص العربى مانى \\ تأثير إستخدام برويوليس نحل العسل كإضافه طبيعيه علي الأداء الإنتاجي والفسيولوجي للسمان الياباني

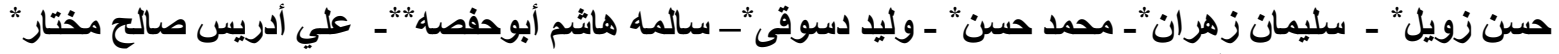

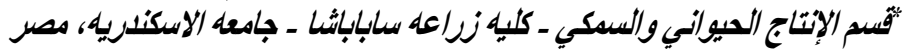

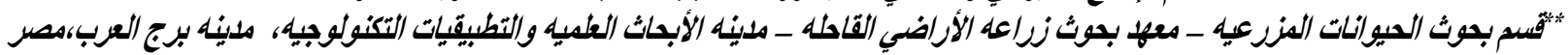

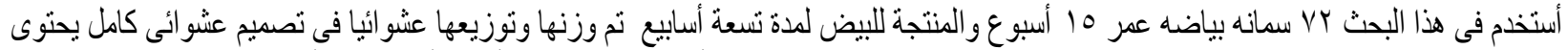

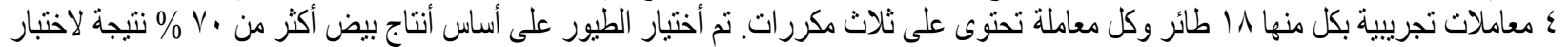

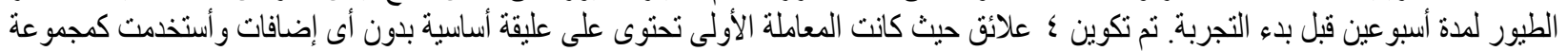

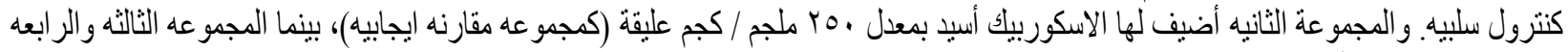

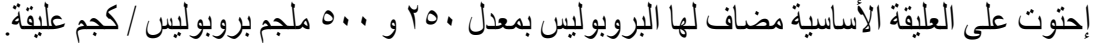

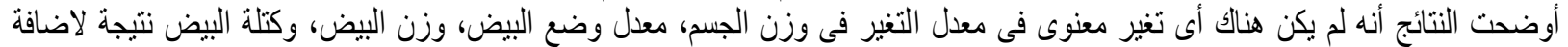

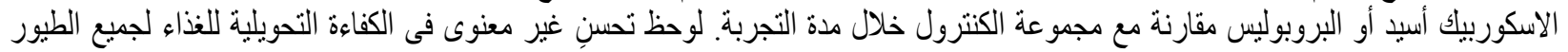

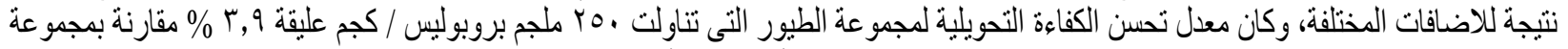

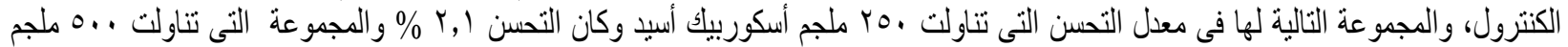

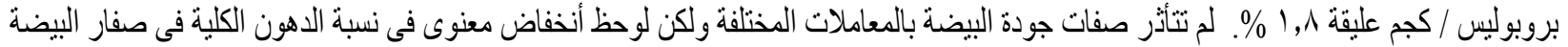

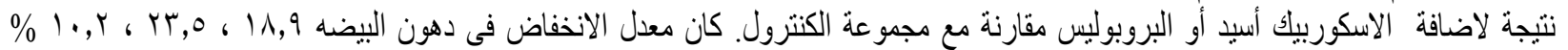

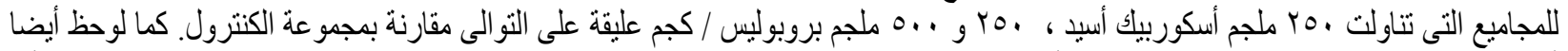

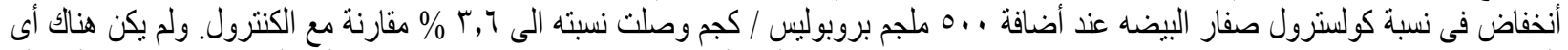

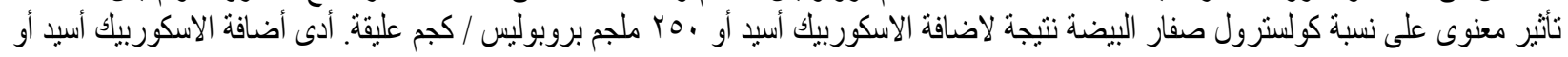

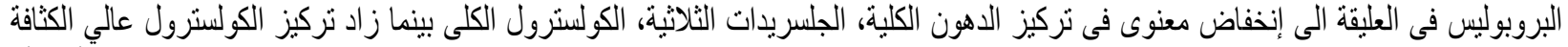

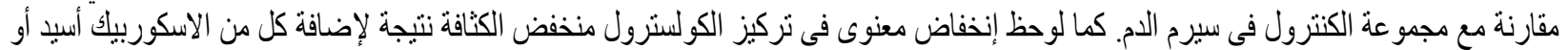

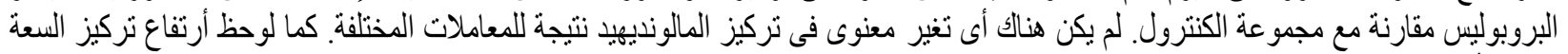

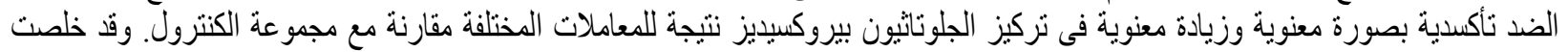

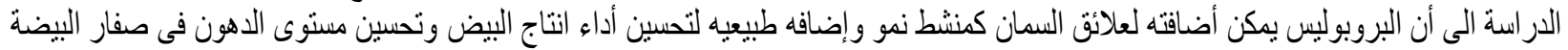
وسبرم الام وتعزيز المناعه كالصفات الضد تأكسدية تحت ظروف الصنيف الصيف الحار. 